\title{
The Benefits of Introducing Non-chromate Technology in Conversion Coating Applied to Aluminum Elements: The ABC Colorex Case Study
}

\author{
Agnieszka Czaplicka-Kotas ${ }^{*}$, Mateusz Figiel $^{\dagger}$ and \\ Marzena Smol ${ }^{*}$ \\ ${ }^{\star} \mathrm{MSc}$ Eng., AGH \\ ${ }^{\dagger} \mathrm{MSc}$ Eng., COLOREX \\ ${ }^{\ddagger} \mathrm{PhD}$, Mineral and Energy Economy Research Institute, \\ Polish Academy of Sciences
}

\section{Introduction}

Environmental regulations attach great importance to the monitoring of production's impact on environment. Currently environmental policy in the European Union is governed by the strategies "Europe 2020", as well as "Sustainable Development", and the "7th EAP Environment Action Programme to 2020". Some postulates of these ideas include eco-design and sustainable design, which aim to minimize the adverse effects of production upon the environment. Due to the implementation of the principles of designing environmentally friendly products, it is possible to avoid high emissions and hazardous waste.

An example of an action that would reduce negative impact upon the environment is to switch from chromate to chromate-free conversion coating applied on aluminum elements. The coating's role is to increase corrosion resistance, reduce friction, increase adhesion of other coatings and obtain decorative effects. The benefits of the transition from chromate to chromate-free coating

How to cite this book chapter:

Czaplicka-Kotas, A., Figiel, M. and Smol, M. 2019. The Benefits of Introducing Nonchromate Technology in Conversion Coating Applied to Aluminum Elements: The ABC Colorex Case Study. In: Gąsior, A. (ed.) Pro-ecological Restructuring of Companies: Case Studies, Pp. 149-158. London: Ubiquity Press. DOI: https://doi. org/10.5334/bbk.m. License: CC-BY 4.0 
leads to an improvement of both its technological roles as well as environmental factors. Technology chromate based on hexavalent chromium is usually used in the industry powder coating due to its very good corrosion-resistant capabilities. However, there is a potential danger of introducing chromium into the environment, because it can cause mutagenic changes and carcinogenic properties to exist within the environment. Therefore, the aim is to introduce a nonchromate treatment, for example, based on compounds of fluorides, titanium, zirconium and organic compounds that are more environmentally friendly.

The company in question, $\mathrm{ABC}$ Colorex Ltd., is a company operating in the field of powder coating and metal processing services. One of the company's strategic goals is to increase production capacity while minimizing the impact of the production on the environment. This plant is an example of the implementation of good practices in the field of production. It is a pioneer in the implementation of non-chromate technology based on titanium compounds.

\section{Ecological Way in Product Design}

One of the main horizontal objectives implemented by the European Commission is to increase the efficiency of raw materials in the Europe 2020 strategy. The measures focus on maintaining balance between environmental policy and demands of the market. Due to an innovative way related to the eco-production and services, as well as better estimation of the life cycle of products in the value chain, they can result in more efficient use of raw materials (Lacy \& Rutqvist 2015). The main idea that stimulates the optimal management of raw materials and energy is the circular economy (CE). This concept relates to the closedloop product lifecycle, which results in an increased re-use of waste.

A potential tool that may influence a more efficient implementation of the circular economy is eco-design, which is defined as "the integration of environmental aspects into product design with the aim of improving the environmental performance of the product throughout its whole life cycle"1. According to the European Comission $^{2}$ activities related to, among others, eco-design and waste prevention can result in minimizing the net expenses by 600 billion euros and reduce annual greenhouse gas emissions by $2-4 \%$. The main purpose of eco-design is to reduce negative factors affecting the environmental life cycle of products (Burchart-Korol 2010). ISO 14062 is the main guideline which regulates relations between the environment and design at every stage of the process (Stachura \& Karwasz 2007).

Designing products according to the principles of sustainable development pertains to two areas: eco-design and sustainable design. One of the conditions for the development of eco-design is sustainable product design. The difference between these two concepts results from the fact that sustainable design also takes into account the following aspects: economical, social and ecological, i.e. it aims for the "triple bottom-line" (Diegel et al. 2016). Vezolli and Manzini identified four fundamental aspects that influence the introduction of 
sustainable system design according to ecological factors, namely the choice of environmentally friendly materials, implementation of the design that brings less ecological damage, creation of a sustainable production-consumption system, promotion of sustainable lifestyle (Vezzoli \& Manzini 2008).

\section{Description of the Company ABC Colorex Ltd.}

$\mathrm{ABC}$ Colorex Ltd. is a company operating in the field of powder coating services and metal processing. In 1992 the first headquarters was opened in Cracow in a two-storey building with the purpose of powder coating services.

In the same year, Technology Center Powder P.U.P.H. Colorex was founded in $\mathrm{ABC}$ Colorex Ltd. The company was developing dynamically, quickly acquiring new satisfied customers, and in a short time it has become the largest provider of powder coating services.

In June 2000, these very elements enabled the launch of new headquarters in Cracow, where a branch under the name ABC Colorex Ltd. was created, which met the standards of the twenty-first century in the field of metal coating. The new plant had more than $3500 \mathrm{~m}^{2}$ of usable area. There were two lines created for hand painting details and chemical baths. The plant meets the most stringent global requirements in the field of chemical surface treatment as well as powder coating materials made of steel and aluminum.

On 21 August 2001, the plant became a member of the Association of Contractors Surface Treatment Aluminum QUALIPOL, which on behalf of Qualicoat from Zurich, conducts continuous monitoring of powder coating with the Quality Mark in terms of production and organization. In the same year, as the fifth company in Poland, it has been awarded a certificate of quality Qualicoat No. 1505 issued by the Association for Quality Control Powder Coating, Paints and Coatings QUALICOAT in Zurich.

Another significant document for the company is a certificate issued in June 2002 by IGP Pulvertechnik, a supplier of powder coatings. The supplier allowed ABC Colorex Ltd. to use paints from a unique series, namely IGP HWF 2001, for which the manufacturer gives 25 -year warranty for coating durability.

The plant has also received other certificates from suppliers of powder coatings such as: Synthatec for HB Fuller lacquers with 25-year warranty period, Akzo Nobel with a 10-year warranty period, Jotun and many others.

In May 2006, ABC Colorex Ltd was certified ISO 9001: 2000 in the field of powder coating, which was issued by the certifying company DEKRA INTERTEK CERTIFICATION.

In 2004, the plant started the first fully automatic lacquering line with a ninestep surface preparation, including phosphorence zinc. It has been dedicated for customers from the household appliances market, who provided numbers of elements. A year later, in Krakow another fully automated line was launched, whose customers are mainly contractors from the automotive industry. 
Further demand for this type of activity has led to the opening of new powder coating lines, both manual and automated ones. In December 2006, the first powder coating line in Poland was created with the process of preparing the surface for elements $15 \mathrm{~m}$ long, and, in exceptional situations, which can implement a technological process for profiles up to $16.8 \mathrm{~m}$ long.

Then, in 2008, a production hall was constructed that is adapted to the needs of a machine park; it was significantly expanded in January 2014. Currently, its total floor area is over $3000 \mathrm{~m}^{2}$. There are machines for metal flashing, such as: laser, guillotine, bending, rolling mill and others related to a specific production. Thanks to this, the area of operations was expanded and customers are provided with comprehensive services.

In 2012, the event that helped the company to gain the leading position in Poland was building a modern production hall with a fully automated powder coating line for aluminum with baths for preparing the surface of chromatefree bathing process.

Currently, the plant has 15 powder coating lines in three locations, including three automatic lines on the area of over $12,000 \mathrm{~m}^{2}$. On premises, there is also the first station in Poland for corrosion monitoring, which has been providing information about the properties of anti-corrosion powder coating for over 15 years.

What distinguished ABC Colorex Ltd. was the introduction in 2006 of innovative technologies in the field of powder coating associated with hot stamping. The execution of décor is based on transferring a pattern made from foil in the process of pigment sublimation on the metal surface covered by a special polyurethane powder by means of modern machinery. The result is a durable yet exceptionally decorative surface which can resemble wood, stone or any other pattern.

\section{Comparison of the Chromate and Chromate-free Processes}

Applying a conversion coating is a method for refining metals and their alloys. It is created in a specific chemical solution during the processes, such as immersion or spraying. The process is divided into two stages. The first one is an artificially induced and controlled corrosion process, followed by a reaction of the anion contained in the solution of the metal cation, which causes insoluble substances and creates a layer that is closely adherent to the element. Coating can be dived into phosphate, chromate, oxide, polymer and oxalate. Its role is to significantly increase corrosion resistance, reduce friction, increase adhesion of other coatings and obtain decorative effects. In the analyzed plant, three kinds of coating are applied: amorphous iron phosphate for steel and chromium and titanium dioxide for elements made from aluminum.

Iron phosphating process is based on a reaction on the metal surface submerged in a solution of phosphoric acid (V) and metal hydrogenphosphate, in this case trivalent iron. The second substance, which is water soluble, reacts with metal, which results in a shift of the chemical balance of a dissolved salt. A 
sparingly soluble salt, iron (III) hydrogenphosphate, is created which infiltrates the intercrystalline areas of the coating. The reaction is as follows (Gumowska, Harańczyk \& Rudnik 2007):

$$
2 \mathrm{Fe}\left(\mathrm{H}_{2} \mathrm{PO}_{4}\right)_{2} \rightarrow \mathrm{Fe}_{2}\left(\mathrm{HPO}_{4}\right)_{3}+\mathrm{H}_{3} \mathrm{PO}_{4}+\mathrm{H}_{2} \uparrow
$$

Phosphating processes is preceded by the process of cleaning and degreasing. Immediately before it an additional washing in demineralized water must be executed to prevent neutralization of the phosphate solution. Phosphate coating has a crystalline structure, porous and thickness in the range of 1-20 $\mu \mathrm{m}$.

Chromate $(\mathrm{Cr}+6)$ yellow - a process where during the electrochemical or chemical treatment for metal elements, the powder coating is immersed in a bath containing compounds such as chromic acid anhydride (VI) $\mathrm{CrO}_{3}$, sodium chromate or potassium. The process may either take the form of immersion or spraying. It is a kind of metal passivation, which significantly improves anticorrosion protection. The surface detail has been subjected to passivation by creating on it an oxide layer during the process of bathing. The process has to be shut down in a controlled way, and the metal needs to be assisted in the transition into ionic form, which means creating a chromate conversion coating. To achieve this effect, one has to add chemical substances consisting of anions such as sulphates or chlorides into a solution containing hexavalent chromium ions. It should also be noted that sulfuric acid (VI), which is a depassivating substance, is another compound occurring during the reaction. The following reaction takes place in the process (Drápala et al. 2007):

$$
\begin{gathered}
\mathrm{Al}+\mathrm{H}_{2} \mathrm{SO}_{4} \rightarrow \mathrm{AlSO}_{4}+\mathrm{H}_{2} \uparrow \\
12 \mathrm{H}_{2}+4 \mathrm{Na}_{2} \mathrm{Cr}_{2} \mathrm{O}_{7}+3 \mathrm{O}_{2} \rightarrow 2 \mathrm{Cr}(\mathrm{OH})_{3}+2 \mathrm{Na}_{2} \mathrm{CrO}_{4}+3 \mathrm{H}_{2} \mathrm{O} \\
2 \mathrm{Cr}(\mathrm{OH})_{3}+\mathrm{Na}_{2} \mathrm{CrO}_{4} \rightarrow \mathrm{Cr}(\mathrm{OH})_{3} \cdot \mathrm{Cr}(\mathrm{OH}) \mathrm{CrO}_{4}+2 \mathrm{NaOH}
\end{gathered}
$$

The creation of the chromate coating is the transformation of aluminum into an ionic form and separation of hydrogen (Reaction 2). On the border solution, the $\mathrm{pH}$ of the metal increasing through the decrease in concentration of hydrogen cations and precipitate appears in the form of chromium hydroxide (VI) (Reaction 3), and then through the creation of layer of water soluble compound $\mathrm{Cr}(\mathrm{OH})_{3} \cdot \mathrm{Cr}(\mathrm{OH}) \mathrm{CrO}_{4}$, which is the anticipated coating (Reaction 4) (ABC Colorex Ltd. External material).

Before this process, a preliminary preparation of the surface and rinsing in demineralized water is required. After that, the rinsing process must be repeated.

The acidity of the bath is $\mathrm{pH} 1.5-2.5$, the temperature is $20-35^{\circ} \mathrm{C}$ and aluminum is immersed in the bath for 5-8 minutes. The time depends on the amount of previously digested aluminum. After chromate treatment, elements have a slightly yellow-green color. The coating is rough, has a thickness of $0.01-1.5 \mu \mathrm{m}$, it is 
watertight, easy to color, abrasion-resistant and has very good adhesion. This treatment (Chromate $\mathrm{Cr}(\mathrm{VI})$ ) is toxic and its waste has a negative impact on the environment. Therefore, in the future, all companies will be obliged by the European Union to withdraw from using this method. For this reason, new alternatives for this treatment are currently being researched. So far, baths containing chromium (III), organic compounds, or inorganic compounds do not give as good final results as hexavalent chromium, therefore it is still widely used.

Titanium dioxide $\left(\mathrm{TiO}_{2}\right)$ conversion coatings is the second kind of chemical treatment of aluminum used in the described plant. It is a chromium-free process based on fluorides of titanium, zirconium and organic compounds. It was introduced on the new Hall X, where the line for powder coating is fully automatic, because of the need to withdraw baths based on hexavalent chromium in the future. This is an immersion process (there is also a spray process), wherein the $\mathrm{pH}$ is $3.1-3.4$. The immersion time is $60-120$ seconds at $25^{\circ} \mathrm{C}$. The obtained coating is colorless, with a thickness of $10-30 \mu \mathrm{m}$ and weight of $3-10 \mathrm{mg}$ of Ti $/ \mathrm{m}^{2}$. The reactions are as follows (Błachowicz 2011):

$$
\begin{gathered}
2 \mathrm{Al}+6 \mathrm{H}^{+} \rightarrow 2 \mathrm{Al}^{3+}+3 \mathrm{H}_{2} \uparrow \\
A l^{3+}+\mathrm{Ti}^{4+}+\mathrm{F}^{-}+4 \mathrm{H}_{2} \mathrm{O} \rightarrow \mathrm{Al}\left(\mathrm{O}_{2} \mathrm{H}\right) \mathrm{Ti}\left(\mathrm{O}_{2} \mathrm{H}\right) \mathrm{F}+6 \mathrm{H}^{+}
\end{gathered}
$$

First, the process of digesting aluminum takes place, resulting in improved adhesion. Due to the presence of hydrogen cations, aluminum cations are released (Reaction 5), which then, reacting with cations of titanium, fluoride anions and water, form a protective conversion coating on the metal surface (Reaction 6).

One of the main goals of the ABC Colorex Ltd. enterprise is introducing efficient production systems as well as realizing the postulates of environmental policies. Implementation of the oxide conversion coating as a replacement for chromate coatings used for aluminum components is an example of their activities.

To obtain a conversion coating, formulations based on hexavalent chrome (Chromate 12 LC Repl) and a non-chromate treatment (Nabutan 810) can be used. The parameters of these two formulations have similar physical and chemical properties (Table 1). A significant difference was observed for treatment times used during spraying, which is related to coating thickness. After the chromate treatment the coating is 15 times thicker than after the chromium-free one. Parameters of the preparations differ also in terms of the value of $\mathrm{pH}$. Chromiumfree passivation shows a different acidity of the solution, and the product itself, which based on complexing compounds, titanium compounds and polymers, in a short time creates a durable metal surface layers of colored interference.

Based on the literature review and internal company research, it has been demonstrated that in terms of corrosion resistance chromate is a more effective technology than non-chromate (Kwiatkowski 2009; Winiarski \& Szczygieł 2012; Rubel, Tomassi \& Ziółkowski 2009; Landra 2002). However, chromate 
Table 1: Comparison of physical and chemical properties of a preparation based on non-chromate treatment and on hexavalent chromium treatment.

\begin{tabular}{|l|l|l|}
\hline \multicolumn{1}{|c|}{ Parametr } & \multicolumn{1}{|c|}{ Chromate 12 LC } & \multicolumn{1}{c|}{ Nabutan 810 } \\
\hline Temperature & $20-35^{\circ} \mathrm{C}$ & $20-35^{\circ} \mathrm{C}$ \\
\hline Processing time (spraying) & $2-5 \mathrm{~min}$. & $15-60 \mathrm{sec}$. \\
\hline Processing time (immersion) & $45-120 \mathrm{sec}$. & $60-120 \mathrm{sec}$. \\
\hline Spray pressure & $0.7-0.9 \mathrm{bar}$ & $0.5-1.0 \mathrm{bar}$ \\
\hline pH value & $1.5-1.9$ & $3.1-3.4$ \\
\hline
\end{tabular}

Source: The safety data sheet for preparation: Chromate 12 LC Repl, Nabutan 810.

treatment has many defects, mainly due to the presence of toxic compounds. In accordance with the principles of sustainable design, the aim is a highly effective product that is also environmentally friendly. Therefore, it seems appropriate to conduct research on increasing corrosion resistance using a non-chromate passivation. The possibilities can be discerned by improving pre-treatment or electrolytic processes (Kwiatkowski 2009).

Recent studies of ABC Colorex Ltd. have shown that the aluminum corrosion resistance associated with the use of non-chromate technology are comparable with those associated with the use of chromate technology. Corrosion tests were conducted on six pieces of 10-centimeter aluminum Machu and salt chamber. The Machu test (accelerated corrosion test) was performed on the three profiles slit on a metal cross $(1 \mathrm{~mm}$ width) and immersed in a mixture based on $\mathrm{NaCl}, \mathrm{CH}_{3} \mathrm{COOH}, \mathrm{H}_{2} \mathrm{O}$ and then heated to $37^{\circ} \mathrm{C}$. After the test, there were no signs of the appearance of corrosion, which proved the very good quality of the chemical preparation (Nabutan 810 ). The other three cut profiles were immersed in the salt spray for 1000 hours. This study was carried out in accordance with standard ISO 9227. After the test, no changes and approaches in excess of $1 \mathrm{~mm}$ in length were detected (Świerczek \& Zając 2013).

A very important aspect of the process of powder coating is the adhesion of the applied paint coating. In order to compare the two variants of the chemical surface preparation prior to painting, ABC Colorex Ltd. performed an adhesion test according to EN ISO 2409. After a crosswise cut was made on the lacquered elements, there were no problems with the adhesion of the coating in both cases $(\mathrm{Gt}=0)$. Comparing the characteristics associated with adhesion, much better results are obtained by processing based on titanium than chromium (VI). The process based on yellow chromate often results in an excessively thick chromium layer, which results in dusting and reduces adhesion. In the case of non-chromate treatment being applied it is possible to have more control over the coating thickness (Świerczek \& Zając 2013).

Another disadvantage of the bath based on the compounds of Cr (VI) is a high share of carcinogenic compounds. In order to regulate the content of 
chromium (VI) in the European Union, the Directive Restriction of Hazardous Substances 2011/65/EU of 8 June 2011 is applied. Chromate baths, due to the high content of toxic substances, encounter limitations; for example, this type of treatment is banned in the food industry (Landra 2002).

In contrast, the chromate method's undoubted advantage is the low cost. Based on the financial analysis performed by ABC Colorex Sp Ltd., which compared the economic and technological factors, it was found that non-chromate processing technology is more demanding than chromate processing technology.

However, the cost may be increased due to the necessity of acid neutralization bath after chromated yellow. During the reduction of chromium it is necessary to acidify the bath; to this end a technical grade of sulfuric acid $94 \%$ is used (the annual consumption of 200 1.). This process is carried out by use of the reduction reaction of $\mathrm{Cr}$ (VI) to $\mathrm{Cr}$ (III) by sodium sulfate (IV) $\left(\mathrm{Na}_{2} \mathrm{SO}_{3}\right.$ ) (1500 kg/year) or hydrazine (750 kg/year). By reducing hexavalent chromium to trivalent chromium $\mathrm{Cr}_{2} \mathrm{O}_{3}$ is precipitated. The colorimetric method is used to control sulfur content. As a result of the acid neutralization bath after the yellow chromate process a hazardous waste code is formed 110105 "Acids not otherwise specified" (ABC Colorex Ltd. IPPC).

It should be stressed that it is much easier to dispose of waste water after nonchromate treatment. Technological sewage after processing yellow chromium has to be recirculated. This process is based on a demineralization water treatment after the yellow chromate is treated with ion exchangers (cation + acid anion). For the regeneration of the cations, hydrochloric acid technical is used (6000 liters / year), and for the regeneration of anions sodium hydroxide (1500 kg / year). During the process of setting on ion exchangers, leachate is produced, which is placed in containers and defined as hazardous waste code $110109 *$ "Sludges and filter cakes containing dangerous substances". Chemical baths after chemical treatment are considered liquid waste which is not taken into account in the balance. The next step is to exchange, and then neutralize. Recovery of water and concentrated salt concentrate takes place in a vacuum evaporator. The recovered water is reused in the process, and the concentrate is considered waste and collected in sealed containers. The amount of waste water in the Colorex plant is $220 \mathrm{~m}^{3}$ per year. Thanks to the recovery, the water is reused in the process (ABC Colorex Ltd. IPPC).

\section{Conclusion}

In recent years, sustainable design and eco design have grown in popularity. They are promoted by the European Union as environmental tools, which are designed to fulfill the demands of the "sustainable development" strategy or the idea of a "circular economy". One of the examples of companies that implement environmentally friendly production is ABC Colorex Ltd. This plant pays attention to the legal conditions as well as efficiency of production. The action that is intended to implement eco design is introducing non-chromate technology in conversion coating applied to aluminum elements. 
Another important aspect in achieving the objectives of environmental policies are the principles of sustainable design. The product is considered in terms of three aspects, ie. economic, social and environmental. Considering the costs, processing based on the compounds of $\mathrm{Cr}(\mathrm{VI})$ is more profitable than nonchromate passivation. However, with reference to the long-term goals, which are associated with the development of innovative technologies that are environmentally friendly, investment in the alternative method of creating of chromate-free conversion coating appears to be better in view of economic factors.

The main reason associated with the reduced use of baths based on hexavalent chromium is their toxic effect on the environment. The yellow chromate process is burdensome for the environment because it emits carcinogenic and mutagenic compounds of chromium, leading to the formation of defects in the chromosomes of organisms. Based on previous studies it was found that regardless of the amount of $\mathrm{Cr}(\mathrm{VI})$ used in the process the reaction was still damaging to the environment.

In terms of technology a yellow chromate treatment undoubtedly has improved properties related to the corrosion resistance. However, current research shows that it is possible to increase the effectiveness of methods of corrosion protection in the chromium-free process. The big advantage of the use of chromium-free conversion coating technology is getting much better adhesion than by using yellow chromate. Non-chromate technology is also associated with easier control of thickness of the coating.

Based on the analysis, it was found that the company ABC Colorex Ltd. implements the principles of sustainable design in the powder coating industry. According to the policy of the European Union, which supports eco design as well as sustainable design, innovative solutions and improvements in production in this chemical sector should be striven for.

\section{Notes}

${ }^{1}$ Directive 2009/125/EC of the European Parliament and of the Council of 21 October 2009 establishing a framework for the setting of ecodesign requirements for energy-related products

${ }^{2}$ Communication from the commission to the European Parliament, the council, the European economic and social committee and the committee of the regions towards a circular economy: A zero-waste programme for Europe.

\section{References}

ABC Colorex Ltd 2008 Integrated Pollution Prevention and Control (IPPC) for Powder Coating.

Błachowicz, E 2011 Proste i skuteczne metody. Chemiczna obróbka powierzchni $w$ malarniach $i w$ innych zakładach produkcyjno-usługowych, Lakiernictwo przemysłowe, nr 3(71), maj - czerwiec, p. 72-74. 
Burchart-Korol, D 2010 Ekoprojektowanie - holistyczne podejście do projektowania (Eco-design-holistic approach to design). Problemy Ekologii (Ecological Issues), 14(3) p. 119-120, maj-czerwiec Available at http:// yadda.icm.edu.pl/yaddaelement/bwmeta1.element.baztecharticle-BAR80005-0016/c/ httpwww_bg_utp_edu_plartpe1-32010burchart.pdf [Last accessed 30.09.2016].

Communication from the commission to the European Parliament, the council, the european economic and social committee and the committee of the regions towards a circular economy: A zero waste programme for Europe.

Diegel, O, Kristav, P, Motte, D and Kianian B 2016 Additive Manufacturing and Its Effect on Sustainable Design [in] Handbook of Sustainability in Additive Manufacturing Volume 1, Springer Singapore, p.77-78.

Directive 2009/125/EC of the European Parliament and of the Council of 21 October 2009 establishing a framework for the setting of ecodesign requirements for energy-related products.

Drápala, J, Kořeny R, Louda, P et al. 2007 Aluminium Materials and Technologies from $A$ to $Z$, Adin, Prešov.

Gumowska, W, Harańczyk, I and Rudnik, E 2007 Korozja i ochrona metali ćwiczenia laboratoryjne, AGH Uczelniane Wydawnictwa Naukowo-Dydaktyczne, Kraków.

Kwiatkowski, L 2009 Podatność na korozję i skuteczność aktualnych metod ochrony przed korozją stopów aluminium stosowanych $w$ budownictwie, Inżynieria powierzchni 4, p. 24-32.

Lacy, P and Rutqvist, J 2015 Waste to Wealth: The Circular Economy Advantage. London: Springer.

Landra, T 2002 Przygotowanie powierzchni odlewów do malowania farbami proszkowymi, Archiwum Odlewnictwa, Rocznik 2, Nr 3 PAN, Katowice p. 79.

Rubel, E, Tomassi P and Ziółkowski, J 2009 Najlepsze Dostępne Techniki (BAT) Wytyczne dla powierzchniowej obróbki metali i tworzyw sztucznych, Instytut Mechaniki Precyzyjnej; Ministerstwo Środowiska, Warszawa, p. 26.

Stachura, M and Karwasz, A 2007 Eko projektowanie w praktyce, Zeszyty Naukowe Politechniki Poznańskiej, Budowa Maszyn i Zarządzanie Produkcją Nr 5, p. 54.

Świerczek, K and Zając, W 2013 Opinia o innowacyjności bezchromowego procesu przygotowania aluminium do lakierowania proszkowego wykonana dla instalacji w firmie ABC Colorez Ltd, Kraków 31 Lipca.

Winiarski, J and Szczygieł, B 2012 Właściwości ochronne bezchromowych powłok konwersyjnych osadzanych z kąpieli na bazie związków Ti(IV), Mn(II) oraz kwasu fosforowego modyfikowanej dodatkiem organicznym, Ochrona przed Korozją 5 p. 224-228.

Vezzoli, C and Manzini, E 2008 Design for Enviromental Sustainability, London: Springer London. 